\title{
Review on Lipophilic and Hydrophilic Extractives in Tissues of Common Beech
}

\section{Pregled lipofilnih i hidrofilnih ekstraktivnih tvari u tkivima obične bukve}

\author{
Review paper • Pregledni rad \\ Received-prispjelo: 19. 2. 2015. \\ Accepted-prihvaćeno: 29. 1. 2016. \\ UDK: $630 * 813.2 ; 674.031 .632 .22$ \\ doi:10.5552/drind.2016.1511
}

\begin{abstract}
Common beech (Fagus sylvatica L.) is one of the most widespread and economically important tree species in Europe and, therefore, represents a potential source of high value added extractives. The aim of this paper was, therefore, to review the existing data regarding the composition of lipophilic and hydrophilic extractives of beech tissues, and the extraction systems and analytical techniques used for their examination. The lipophilic extractable fraction of beech is characterized mainly by saturated and unsaturated fatty acids, fatty alcohols and sterols while the hydrophilic extractives of beech consist of soluble sugars, i.e. monosaccharides, oligosaccharides, sugar alcohols and sugar acids, as well as of simple phenols and flavonoids. Chromatography has been recognized as the convenient and most frequently used technique for the chemical analysis of extractives. This overview showed that the information about the composition of low-molecular extractives of beech is satisfactory, but the data on oligomeric extractives are still fragmentary.
\end{abstract}

Key words: beech, extractives, fatty acids, sterols, sugars, phenols, catechin, chromatography

SAŽETAK • Obična bukva (Fagus sylvatica L.) jedna je od najrasprostranjenijih i gospodarski najvažnijih vrsta drva u Europi i stoga je potencijalni izvor ekstraktivnih tvari visoke dodatne vrijednosti. Cilj rada bio je preispitati postojeće podatke koji se odnose na sastav lipofilnih i hidrofilnih ekstraktivnih tvari u tkivima bukve te sustave za ekstrakciju $i$ analitičke tehnike koje se primjenjuju za njihovo istraživanje. Lipofilne frakcije koje se mogu ekstrahirati iz bukve uglavnom su zasićene i nezasićene masne kiseline, masni alkoholi i sterol, dok se hidrofilne ekstraktivne tvari iz bukve sastoje od topljivih šećera, tj. monosaharida, oligosaharida, šéernih alkohola $i$ šéernih kiselina, kao i od jednostavnih fenola i flavonoida. Kromatografija je prepoznata kao prikladna i najčešće primjenjivana tehnika kemijske analize ekstraktivnih tvari. Ovaj je pregled pokazao da su podaci o sastavu niskomolekularnih ekstraktivnih tvari iz bukve zadovoljavajući, ali su podaci o oligomernim ekstraktivnim tvarima još uvijek fragmentarni.

Ključne riječi: bukva, ekstraktivne tvari, masne kiseline, steroli, šećeri, fenoli, katehin, kromatografija

\footnotetext{
${ }^{1}$ Authors are scientist, professor and assistant professor at Department of Wood Science and Technology, Biotechnical Faculty, University of Ljubljana, Ljubljana, Slovenia.

Autori su znanstvenik, profesor i docentica Odjela za znanost o drvu i tehnologiju, Biotehnički fakultet, Sveučilište u Ljubljani, Ljubljana, Slovenija.
} 


\section{INTRODUCTION}

\section{UVOD}

Utilization of hardwood represents one of the main industrial and research issues of the wood sector in Europe. Common beech (Fagus sylvatica L.) accounts for approximately one third of the wood stock in Slovenian forests (Report of Slovenian Forest Service for 2011) and represents an economically important tree species with a relatively high potential in wood industry. One of the main deficiencies of this tree species is its tendency to develop discoloured wood in the central part of the tree, also known as the red heart (Bosshard, 1974; Torelli, 1984). Red heart in beech has been investigated from various aspects, ranging from physiology, gross and minute anatomy, chemical composition and physical, mechanical and technological properties (Dietrichs, 1964a; Bauch, 1984; Sachsse, 1991; Torelli et al., 1994; Baum and Schwarze, 2002; Koch et al., 2003; Hofmann et al., 2004; Wernsdörfer et al., 2005; Oven et al., 2008; Mali et al., 2009; Vek et al., 2014; Vek et al., 2015). Generally, if compared to the unaffected wood, the value of discoloured round wood, as well as wood elements on the market, is usually lower (Zell et al., 2004) and, therefore, attempts were made to commercially promote discoloured beech wood (Koch, 2002). In addition to the main structural components of the cell wall, i.e. cellulose, hemicelluloses and lignin, different tissues of a living tree also contain smaller amounts of compounds, which can be removed from the plant tissue with the process of extraction and are, therefore, known as extractives. These are natural low-molecular compounds, the non-structural components of wood, located in the lumina of cells and extraneous to a lignocellulose cell wall. From the physiological aspect of view, the extractive compounds of plant tissue are primary and secondary metabolites (Rowe and Conner, 1979; Fengel and Wegener, 1989; Kai, 1991; Holmbom, 1999). Primary metabolites are present in every plant species, whereas specific secondary metabolites can be found only in some tree species or related group of species. Secondary metabolites were sometimes referred to as accessory compounds (Fengel and Wegener, 1989), because their important ecological functions in the tree have not been understood for a long time. It is known that these in general contribute to protection of plants and against herbivories and microbial pathogens, serve as attractants for pollinators and seed-dispersing animals and function as agents of plant-plant competition and plant-microbe symbioses (Taiz and Zeiger, 2002).

Extractives can be classified according to their chemical similarities, with respect to biochemical paths of their synthesis or regarding the solvent, in which they are soluble. Based on solubility, extractives are divided into classes of lipophilic and hydrophilic extractives (Willför et al., 2006; Jansson and Nilvebrant, 2009).

As proposed by Holmbom (1999), extractives are usually analyzed at three levels, i.e. gravimetric determination of total extractives, determination of different component groups and analysis of individual components. The first level of extractive analysis includes gravimetric and other determination of total extractives. It is generally known that the xylem of tree species in the temperate climate zone contains a relatively small amount of extractives, up to 5 - $10 \%$ (Umezawa, 2000). Anyway, the concentration can be much higher in certain parts of the tree, e.g. in branch bases, bark and roots. Moreover, higher amounts of extractives are also found in some tropical and subtropical woods (Fengel and Wegener, 1989; Holmbom, 1999). As reported by Wagenführ (1996), beech wood consists of $33.7 \%$ to $46.4 \%$ of cellulose, $11.6 \%$ to $22.7 \%$ of lignin, $11.8 \%$ to $25.5 \%$ of hemicelluloses, $3 \%$ to $5 \%$ of extractives, meanwhile the share of inorganic compounds represents $0.3 \%$ to $1.2 \%$. By applying standardized analytical methods used in wood chemistry, $47.66 \%$ of cellulose, $25.53 \%$ of lignin, $69.01 \%$ of holocellulose, $0.93 \%$ substances soluble in benzene-alcohol, $2 \%$ of substances soluble in hot water, $13.15 \%$ substances soluble in $1 \% \mathrm{NaOH}$ and $0.3 \%$ of mineral substances (ash) were determined by Bodirlau et al. (2008). The $\mathrm{pH}$ value of beech wood ranges from 5.06 up to 5.13 (Hillis, 1987). Fengel and Wegener (1989) stated that the average $\mathrm{pH}$ value is 5.4. Even more, authors reported that the $\mathrm{pH}$ value of cold water extract is 5.5, while the $\mathrm{pH}$ value of hot water extract is slightly lower (5.3). Sixta et al. (2004) found $24.2 \%$ of lignin in freshly prepared beech wood chips. Further carbohydrate analysis revealed $41.6 \%$ glucan, $17.9 \%$ xylan, $1.3 \%$ mannan, $1.2 \%$ galactan and $0.5 \%$ arabinan (Sixta et al., 2004). It was reported that intact sapwood contains less lignin (19.75\%) than biologically decayed wood (20.82 \%) (Košikova et al., 2008), whereas the origin of decay was not described in this research. Generally, beech wood is characterized by a relatively low amount of extractives (Rowe and Conner, 1979). Furthermore, the information regarding the content and composition of extractives in beech wood is poor. In the case of fresh beech wood chips, Sixta et al. (2004) stated that $0.2 \%$ of the compound are extracted with dichloromethane, $1.0 \%$ with acetone, $1.7 \%$ of extractives are soluble in ethanol, while $2.7 \%$ are obtained with water. According to Košikova et al. (2008), in comparison to healthy sapwood, from which $1.78 \%$ of extractives were gained, decayed wood contains less extractives soluble in acetone, i.e. $0.98 \%$. Furthermore, Kubel and Weissmann (1988) report that the amount of extractives, soluble in petrol ether and diethyl ether, is relatively low and it amounts to $0.2 \%$ and $0.1 \%$, respectively. More compounds can be extracted by the mixture of alcohols and water, $1.6 \%$ with acetone/water (9:1, $\mathrm{v} / \mathrm{v})$ and $1.2 \%$ with ethanol/water $(8: 2, \mathrm{v} / \mathrm{v})$. A relatively low amount of water soluble extractives $(0.3 \%)$ can be attributed to the successive extraction procedure.

The basic gravimetrical estimation of the amount of total extractives is usually upgraded by the second and third level of analyses, i.e. determination of the component groups in extracts and evaluation of composition of individual extractives. For the determination of groups of extractives in wood extracts, e.g. total phenols, flavonoids or proanthocyanidins, a spectrophoto- 
metric analysis (UV-Vis) represents a quick and reliable technique (Baum and Schwarze, 2002; Albert et al., 2003; Brighente et al., 2007; Vek et al., 2013a; Vek et $a l ., 2013 \mathrm{~b}$ ). The lack of semi-qualitative evaluation is that UV-Vis analysis gives relative and not absolute results as a consequence that the amount of component group is estimated towards the component of external standard, e.g. gallic acid, quercetin of catechin. Therefore, more precise chromatographic techniques are used, i.e. thin-layer chromatography (TLC), gas chromatography (GC) or high performance liquid chromatography (HPLC). Qualitative determination is possible by the ${ }^{13} \mathrm{C}$ NMR and eventually with Furrier transform infrared spectroscopy (FTIR) as well. Furthermore, for the determination of different groups of extractives by means of HPLC, both the size-exclusion (HPLC-SEC) and reversed-phase (RP) modes can be applied. Precise qualitative evaluation of individual compounds separated by chromatographic techniques (GC or HPLC) is most conveniently made by mass spectrometry (MS). Therefore, GC/MS and HPLC/MS represent an adequate technique for the identification of extractives in complex mixtures such as plant extract.

The aim of the present work was to review the literature on extractives, which have been qualitatively evaluated as the extracts of beech tissue so far. In the following, the results of various chemical analyses of extrac- tives occurring in different types of beech tissue are presented separately for lipophilic and hydrophilic components (Holmbom, 1999; Naczk and Shahidi, 2007).

\section{EXTRACTIVES OF BEECH}

\section{EKSTRAKTIVNE TVARI U TKIVIMA BUKVE}

\subsection{Lipophilic extractives}

2.1. Lipofilne ekstraktivne tvari

Lipophilic extractives are referred to as the compounds which are soluble in nonpolar organic solvents, e.g. pentane, hexane, petroleum ether, dichloromethane, chloroform or toluene. It is well known that lipophilic extractives can have a negative influence and may disturb the analysis of more polar compounds. Moreover, they may have a deleterious effects on chromatographic instrumentation due to column clogging (Slanina and Glatz, 2004). Therefore, it is recommended first to remove the lipophilic extractives from the sample before further extraction with polar solvents (Naczk and Shahidi, 2004; Willför et al., 2006). Waxes, fats, fatty alcohols, fatty acids, terpenoids, sterols and steryl esters are known as the characteristic representatives of lipophilic extractives. Some of them were also identified in the nonpolar extractible fraction of beech.

In the case of beech wood dust, extracts were characterized by a relatively low amount of lipophilic

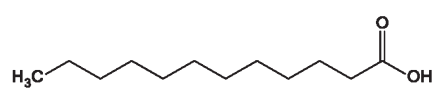

(1)

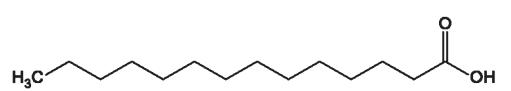

(2)

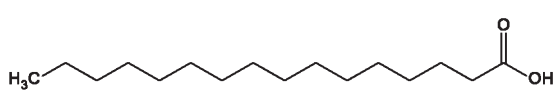

(3)<smiles>CCCCCCCCCCCCCCCCCC(=O)O</smiles>

(4)<smiles>CCCCCCCCCCCCCCCCCCCCCC(=O)O</smiles>

(6)<smiles>CCCCCC/C=C\CCCCCCCC(=O)O</smiles>

(8)<smiles>CCCCCCCC/C=C/CCCCCCCC(=O)O</smiles>

(10)<smiles>CCCCCCCCCCCCCCCCCCCC(=O)O</smiles>

(5)<smiles>CCCCCCCCCCCCCCCCCCCCCCCC(=O)O</smiles>

(7)
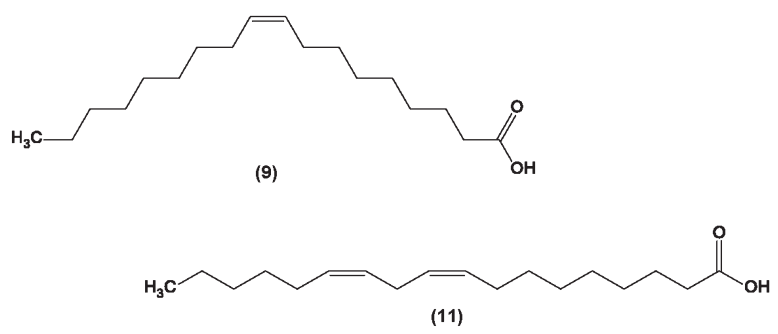

(11)<smiles>CC/C=C/C/C=C/C/C=C/CCCCCCCC(=O)O</smiles>

Figure 1 Structure formulas of saturated and unsaturated fatty acids identified in the extracts of beech: (1) Lauric C12:0 acid; (2) Myristic C14:0 acid; (3) Palmitic C16:0 acid; (4) Stearic C18:0 acid; (5) Arachidic C20:0 acid; (6) Behenic C22:0 acid; (7) Lignoceric C24:0 acid; (8) Palmitoleic C16:1 acid; (9) Oleic C18:1 acid; (10) Elaidic C18:1 acid; (11) Linoleic C18:2 acid; (12) Linolenic C18:3 acid

Slika 1. Strukturne formule zasićenih i nezasićenih masnih kiselina identificiranih u ekstraktivnim tvarima bukve: (1) laurinska C12:0 kiselina; (2) miristinska C14:0 kiselina; (3) palmitinska C16:0 kiselina; (4) stearinska C18:0 kiselina; (5) arahidonska C20:0 kiselina; (6) behenska C22:0 kiselina; (7) lignocerinska C24:0 kiselina; (8) palmitoleinska C16:1 kiselina; (9) oleinska C18:1 kiselina; (10) elaidinska C18:1 kiselina; (11) linolna C18:2 kiselina; (12) linolenska C18:3 kiselina 


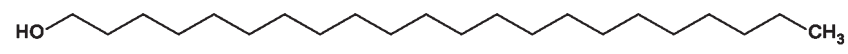

(1)

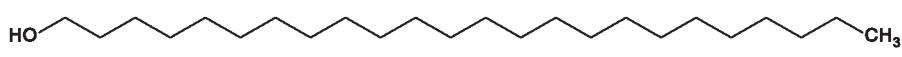

(2)

Figure 2 Structures of fatty alcohols found in the cyclohexane extracts of beech wood: (1) Behenyl C22:0 alcohol; (2) Lignoceryl C24:0 alcohol

Slika 2. Strukture masnih alkohola pronađenih u cikloheksanskim ekstraktima bukovine: (1) behenil C22:0 alkohol; (2) lignocerinski C24:0 alkohol

extractives (Kubel and Weissmann, 1988). In the nonpolar extracts of sapwood and wood chips of beech, saturated and unsaturated fatty acids were identified as the palmitic (C16:0), stearic (C18:0), oleic (C18:1) and linoleic (C18:2) acid by means of different chromatographic techniques (Kubel and Weissmann, 1988; Zule and Može, 2003). Moreover, a saturated lauric (C12:0), myristic (C14:0), arachidic (C20:0), behenic (C22:0) and lignoceric acid (C24:0) and unsaturated palmitoleic (C16:1), elaidic (C18:1), linolenic (18:3), dehydroabietic and unsaturated hydroxyoctadecadiene acid were identified in the extracts of sapwood as well (Figure 1 Structure formulas of saturated and unsaturated fatty acids identified in the extracts of beech: (1) Lauric C12:0 acid; (2) Myristic C14:0 acid; (3) Palmitic C16:0 acid; (4) Stearic C18:0 acid; (5) Arachidic C20:0 acid; (6) Behenic C22:0 acid; (7) Lignoceric C24:0 acid; (8) Palmitoleic C16:1 acid; (9) Oleic C18:1 acid; (10) Elaidic C18:1 acid; (11) Linoleic C18:2 acid; (12) Linolenic C18:3 acid (Figure 1) also represent a part of the aliphatic fraction in suberin (Perra et al., 1993), a hy- drophobic biopolymer, whose occurrence is characteristic for wound response of wood in beech (Pearce, 1996; Torelli and Oven, 1996; Oven et al., 1999; Pearce, 2000; Schwarze and Baum, 2000). The presence of fatty alcohols, i.e. behenyl C22:00 alcohol and lingoceryl C24:0 (Figure 2 Structures of fatty alcohols found in the cyclohexane extracts of beech wood: (1) Behenyl C22:0 alcohol; (2) Lignoceryl C24:0 (Figure 2 ), has been recently proven in the cyclohexane extracts of wood of red hearted beech by the long-column GC/MS analysis (Vek et al., 2014). Besides fatty acids, the extracts of beech knots are also characterized by a low concentration of resin acids (Lindberg et al., 2004). In addition to fatty acids and alcohols, numerous glycerides, sterols and steryl esters were identified as the lipophilic extractives of beech wood. An acyclic triterpenoid squalene (Figure 3) and cyclic cycloartenyl acetat, $\beta$-amyrin acetate, acetyl methyl betulinate and dihydrositosterol were extracted from dried wood by Pišova and Souček (1973). Furthermore, relatively low levels of $\beta$-carotene and lutein were found in the<smiles>CC(C)=CCC/C(C)=C/CC/C(C)=C/CC/C=C(\C)CC/C=C(\C)CCC=C(C)C</smiles><smiles>CCC(CC[C@@H](C)C1CC[C@H]2[C@H]3CCC4C[C@@H](O)CC[C@]4(C)[C@H]3CC[C@]12C)C(C)C</smiles>

(2)<smiles>CCC(CCC(C)[C@H]1CC[C@H]2[C@H]3CC=C4C=CCC[C@]4(C)[C@H]3CC[C@@]21C)C(C)C</smiles>

(5)<smiles></smiles>

(3)

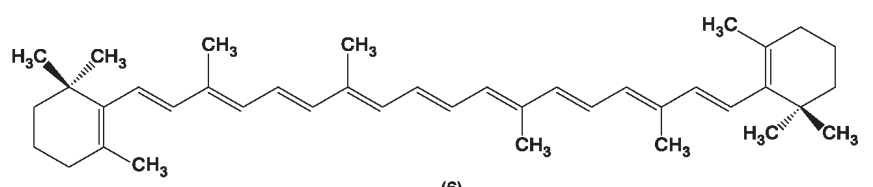

(6)

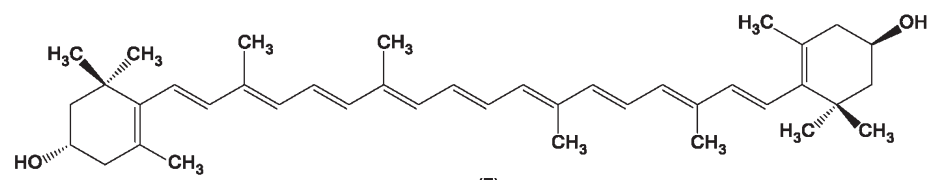

(7)

Figure 3 Structure formulas of terpenoids, i.e. acyclic triterpene, sterols tetraterpenes, occurring in beech wood: (1) Squalene; (2) $\beta$-sitostanol; (3) $\beta$-sitostanol; (4) Campesterol; (5) Stigmastadiene; (6) $\beta$-carotene; (7) Lutein. Slika 3. Strukturne formule terpenoida, tj. acikličkih triterpena, sterolnih tetraterpena koji se pojavljuju u drvu bukve: (1) skvalen; (2) $\beta$-sitostanol; (3) $\beta$-sitostanol; (4) kampesterol; (5) stigmastadien; (6) $\beta$-karoten; (7) lutein 
sapwood extracts of beech by Masson et al. (1997). This was actually the first report about the presence of carotenoids in wood tissue (Figure 3). As shown in Figure 3, a $\beta$-sitosterol, dihydrositosterol ( $\beta$-sitostanol) and campesterol were qualitatively evaluated as the free sterols occurring in various beech materials, i.e. sapwood dust, wood chips and dried wood (Pišova and Souček, 1973; Kubel and Weissmann, 1988; Zule and Može, 2003). Furthermore, Zule and Može (2003) described $\beta$-sitosterol as the most important unesterified sterol in beech wood with a very significant physiological function in wood. Sterols were also found in beech knots (Lindberg et al., 2004). As recently reported (Vek et al., 2014), a characteristic compound of the nonpolar fraction of extractives in beech wood is also stigmasta-3,5-diene (Figure 3) that belongs to the group of sterenes, known as the dehydration compounds of sterols (Gallina Toschi et al., 1996; Amelio et al., 1998). Lindberg et al. (2004) reported on the presence of sterols in the extract of beech knots.

\subsection{Hydrophilic extractives}

\subsection{Hidrofilne ekstraktivne tvari}

After removing lipophilic extractives, the hydrophilic compounds are usually further extracted by means of more polar solvents, such as methanol, ace- tone, ethanol, water, etc. Soluble sugars and various phenolic extractives, e.g. simple phenolics, stilbenes, lignans, flavonoids and tannins are known as the characteristic representatives of hydrophilic extractives. In a broader sense, inorganic compounds are also known as hydrophilic extractives and they can be extracted by water (Fengel and Wegener, 1989). The yield of hydrophilic extractives from beech wood is usually much larger than that of lipophilic extractives (Kubel and Weissmann, 1988).

Various monosaccharides and oligosaccharides, sugar alcohols and acids, simple phenolics, flavonoids, both oligomeric units of tannins have been determined as the hydrophilic substances of beech wood. Among the monosaccharides, glucose, galactose, arabinose, fructose, xylose, mannose and rhamnose were identified in the wood extracts and wood condensate of beech (Dietrichs, 1964b; Kubel and Weissmann, 1988; Irmouli et al., 2002). Furthermore, disaccharides saccharose and trehalose as well as trisaccharide raffinose were identified in the extracts of beech wood (Dietrichs, 1964b; Vek et al., 2014). The presence of both tetrasaccharide stachyose and polysaccharide starch was reported for the sapwood and wood condensate of beech, respectively (Dietrichs, 1964b; Irmouli et al., 2002). Sugar alcohols, i.e. erytritol, arabitol, sorbitol, mannitol, xylitol

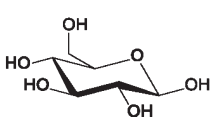

(1)

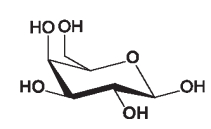

(2)

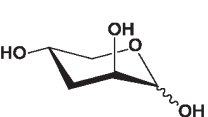

(3)

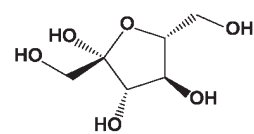

(4)

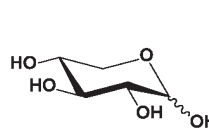

(5)

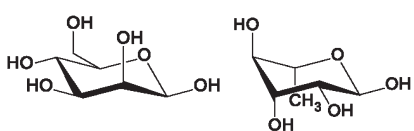

(6)

(7)
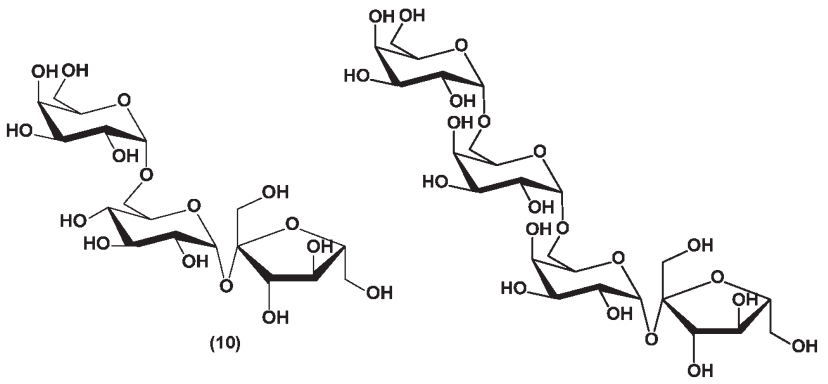

(11)<smiles>OC[C@@H](O)C(O)[C@H](O)CO</smiles>

(14)<smiles>OC1C(O)C(O)C(O)C(O)C1O</smiles>

(17)

(18)

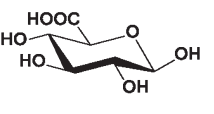

(22)

Figure 4 Chemical structures of monosaccharides, oligosaccharides, sugar alcohols and sugar acids identified in beech wood:

(1) Glucose; (2) Galactose; (3) Arabinose; (4) Fructose; (5) Xylose; (6) Mannose; (7) Rhamnose; (8) Saccharose;

(9) Trehalose; (10) Raffinose; (11) Stachyose; (12) Arabitol; (13) Mannitol; (14) Xylitol; (15) Erytritol; (16) Sorbitol;

(17) Glicerol; (18) Inositol; (19) Threonic acid; (20) Ribonic acid; (21) Gluconic acid; (22) Glucuronic acid

Slika 4. Kemijska struktura monosaharida, oligosaharida, šećernih alkohola i šećernih kiselina identificiranih u drvu bukve:

(1) glukoza; (2) galaktoza; (3) arabinoza; (4) fruktoza; (5) ksiloza; (6) manoza; (7) ramnoza; (8) saharoza; (9) trehaloza;

(10) rafinoza; (11) stahioza; (12) arabitol; (13) manitol; (14) ksilitol; (15) eritritol; (16) sorbitol; (17) glicerol; (18) inozitol;

(19) treonska kiselina; (20) ribonska kiselina; (21) glukonska kiseline; (22) glukuronska kiselina 
<smiles>O=C(O)CC(O)C(=O)O</smiles>

(1)<smiles>O=C(O)CC(=O)O</smiles>

(2)<smiles>O=C(O)CC(O)(CC(=O)O)C(=O)O</smiles>

(3)

Figure 5 Structure formulas of carboxylic acids identified in methanolic extracts of beech wood: (1) Malic acid; (2) Malonic acid; (3) Citric acid

Slika 5. Strukturne formule karboksilnih kiselina identificiranih u metanolnim ekstraktima iz bukovine: (1) jabučna kiselina; (2) malonska kiselina; (3) limunska kiselina

and glycerol, as well as inositols were qualitatively evaluated in extracts of wound-associated tissues and knots of beech (Zule and Može, 2003; Vek et al., 2014). In addition to sugar alcohols, the occurrence of several sugar acids (ribonic, threonic, gluconic and glucuronic acid) has been proven for the methanol extracts of stem wood by means of GC/MS (Figure 4). Our recent chromatographic study has also shown the presence of lowmolecular carboxylic acids in the extracts of both stem wood and knots of beech, i.e. malic, malonic and citric acid (Figure 5) (Vek et al., 2014).

Numerous simple phenols have been extracted from beech wood as well. Challinor (1996) applied gas chromatography coupled with mass spectrometry for the qualitative evaluation of extractives in the wood shavings/turnings of intact beech. As the characteristic compounds in the tetramethylammonium hydroxide extracts, 5-hydroxy, 2-hydroxymethyl pyranone (triv. kojic acid), 3,4-dimethoxybenzaldehyde, 3,4-dimethoxybenzoic acid methyl ester, 3,4,5-trimethoxybenzaldehyde and 3,4,5-trimethoxybenzoic acid methyl ester were found. From thermal treated wood, i.e. steamed and dried beech wood, a sinapyl alcohol, coniferyl alcohol, 2,6-dimethoxybenzoquinone, protocatechuic acid, vanillic acid, vanillin, syringic acid, coniferaldehyde, siringalydehide synapic acid, gallic acid, p-hy-<smiles>COc1cc(CO)ccc1O</smiles>

(1)<smiles>COc1cccc(OC)c1O</smiles>

(2)<smiles>COc1cc(C(=O)O)ccc1O</smiles>

(3)<smiles>COc1cc(C(=O)O)cc(OC)c1O</smiles>

(4)<smiles>O=C(O)c1cc(O)c(O)c(O)c1</smiles>

(5)<smiles>CC/C=C/c1cc(OC)c(O)c(OC)c1</smiles>

(6)<smiles>COc1cc(C(=O)O)cc(OC)c1OC</smiles>

(10)<smiles>COc1cc(/C=C/CO)ccc1O</smiles>

(11)<smiles>COC1=CC(=O)C=C(OC)C1=O</smiles>

(12)

(8)

(9)<smiles>COc1cc(/C=C/C=O)ccc1O</smiles>

(14)<smiles>COc1cc(/C=C/C(=O)O)cc(OC)c1O</smiles>

(15)<smiles>O=C(O)c1ccc(O)cc1</smiles>

(16)<smiles>COc1cc(C=O)cc(OC)c1O</smiles>

(17)<smiles>O=C(O)c1ccc(O)c(O)c1</smiles>

(18)

Figure 6 Structure formulas of simple phenolics identified in beech wood extracts: (1) Vanilyl alcohol; (2) Syringol; (3) Vanillic acid; (4) Syringic acid; (5) Gallic acid; (6) Sinapyl alcohol; (7) Kojic acid; (8) 3,4-Dimethoxybenzaldehyde; (9) 3,4,5-Trimethoxybenzaldehyde; (10) 3,4,5-trimethoxybenzoic acid; (11) Coniferyl alcohol; (12) 2,6-Dimethoxybenzoquinone; (13) Vanilin; (14) Coniferaldehyde; (15) Synapic acid; (16) p-Hydroxybenzoic acid; (17) Syringaldehyde; (18) Protocatechuic acid

Slika 6. Strukturne formule jednostavnih fenola identificiranih u ekstraktima iz bukovine: (1) vanilil alkohol; (2) siringol; (3) vanilinska kiselina; (4) siringijska kiselina; (5) galna kiselina; (6) sinapil alkohol; (7) Kojić kiselina; (8) 3,4-dimetoksibenzaldehid; (9) 3,4,5-trimetoksibenzaldehid; (10) 3,4,5-trimetoksibenzojeva kiselina; (11) koniferil alkohol; (12) 2,6-dimetoksibenzokinon; (13) vanilin; (14) koniferaldehid; (15) sinapik kiselina; (16) p-hidroksibenzojeva kiselina; (17) siringaldehid; (18) protokatehična kiselina 
<smiles>O=c1cc(-c2ccc(O)cc2)oc2cc(O)cc(O)c12</smiles>

(1)<smiles>Oc1cc(O)c2c(c1)O[C@H](c1ccc(O)c(O)c1)[C@H](O)C2</smiles>

(4)<smiles>O=c1c(O)c(-c2ccc(O)cc2)oc2cc(O)cc(O)c12</smiles>

(2)<smiles>Oc1cc(O)c2c(c1)O[C@H](c1ccc(O)c(O)c1)[C@H](O)C2</smiles>

(5)<smiles>O=c1c(O)c(-c2ccc(O)c(O)c2)oc2cc(O)cc(O)c12</smiles>

(3)<smiles>O=C1c2c(O)cc(O)cc2O[C@H](c2ccc(O)c(O)c2)[C@@H]1O</smiles>

(6)

Figure 7 Flavonoids found in the extracts of functional wood, discoloured wood, dried wood, leaves, bark and roots of beech: (1) Apigenin; (2) Kaempferol; (3) Quercetin; (4) Catechin; (5) Epicatechin; (6) Taxifolin

Slika 7. Flavonoidi pronađeni u ekstraktima funkcionalnog drva, izbijeljenog drva, osušenog drva, lišća, kore i korijena bukve: (1) apigenin; (2) kempferol; (3) kvercetin; (4) katehin; (5) epikatehin; (6) taksifolin

droxybenzoic acid were successfully extracted and qualitatively evaluated (Irmouli et al., 2002; Koch et al., 2003; Mounguengui et al., 2007; Vek et al., 2014). Moreover, vanillin, vanillic acid and syringic acid are also known as the constituents of phenolic fraction of a depolymerized suberin in beech (Perra et al., 1993). In addition to simple phenols, the presence of aromatic dimeric structures, i.e. lignin-type compounds, was also proven in beech wood extracts (Koch et al., 2003; Vek et al., 2014). These dimers made up of coniferyl and sinapyl alcohol were referred to as the precursors of a lignin biosynthesis accordingly to Koch et al. (2003), but they can represent another group of phenolic extractives, called lignans. Lignans were found in extracts of beech knot by Lindberg et al. (2004). Furthermore, they reported about the presence of small amounts of stilbenes, generally known as bioactive compounds with the 1,2-diphenylethene structure (Lindberg et al., 2004). Some of simple phenolic compounds that have been shown as the extractives of beech wood are presented in Figure 6.

Flavonoids are commonly referred to as both the most important and abundant group of extractives of beech tissue (Brignolas et al., 1995; Pearce, 1996; Torelli, 2003; Vek, 2013). Catechin is the most frequently reported flavonoid that can be extracted from the beech wood (Figure 7). A few research groups reported on the presence of catechin in the sapwood and discoloured wood (Kubel and Weissmann, 1988; Baum and Schwarze, 2002; Koch et al., 2003; Zule and Može, 2003; Hofmann et al., 2004; 2008). Catechin was also found in the extracts of thermally treated and decayed beech wood (Mounguengui et al., 2007; Lekounougou et al., 2008). It was reported that the amount of catechin in discoloured tissues decreases due to its participation in the process of formation of colour chromophores (Hofmann et al., 2004). It was also suggested that, during thermal treatment of beech wood, the condensation of catechin contributes to a brown stain pig- ment, whereas other extractives, e.g. a 2,6-dimethoxybenzoquinone (Figure 6) and taxifolin (Figure 7), contribute to the final colour of discoloured tissues (Koch et al., 2003). Therefore, the discolouration mechanism in beech wood can be understood as a condensation of catechin monomers to polymer forms. Besides wood, the presence of flavonoids has also been shown for the extracts of other parts of beech tree, e.g. leaves, knots, roots and bark (Beyeler and Heyser, 1997; Dubeler et al., 1997; Feucht et al., 1997; Lindberg et al., 2004; Pietarinen et al., 2006; Pirvu et al., 2010). In addition to the catechin, its diastereomer epicatechin was also found both in beech wood and in roots and leaves (Beyeler and Heyser, 1997; Feucht et al., 1997; Hofmann et al., 2004). As reported by Pirvu et al. (2010), a flavone apigenin, flavonols kaempferol and quercetin and various caffeic acid derivates can be extracted with ethanol from beech leaves (Figure 7). Recently, a comprehensive investigation, with the high-performance liquid chromatography and multistage mass spectrometry, has shown the presence of catechin and epicatechin in beech bark extracts (Hofmann et al., 2015).

Phenolic compounds frequently occur as glycosides as the core aglycone in plant tissues. According to Sherwood and Bonello (2013), the sugar unit of phenolic glycoside serves to improve solubility for storage in cell organs, e.g. vacuoles. Some research groups described the presence of flavonoid glycosides as characteristic for beech extracts (Figure 8). Catechin glucoside and taxifolin glucoside were found in the extracts of both normal and thermally treated beech wood (Kubel and Weissmann, 1988; Koch et al., 2003). Numerous glycosides, i.e. taxifolin- $O$-pentoside, taxifolin- $O$-hexoside, quercetin- $O$-pentoside and quercetin$O$-hexoside were proven to occur in the methanol extracts of wood dust by Mammela (2001). The presence of glycosides was confirmed in the extracts of beech bark as well. Thus, cis-coniferin, cis-syringin, 


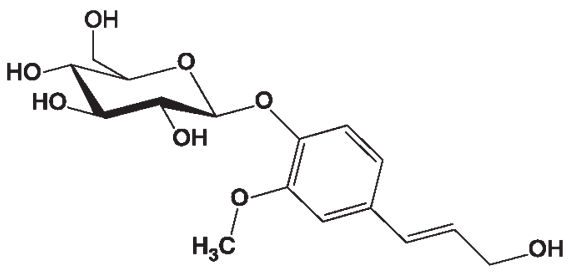

(1)

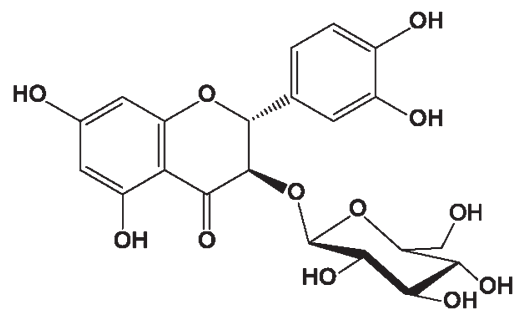

(3)

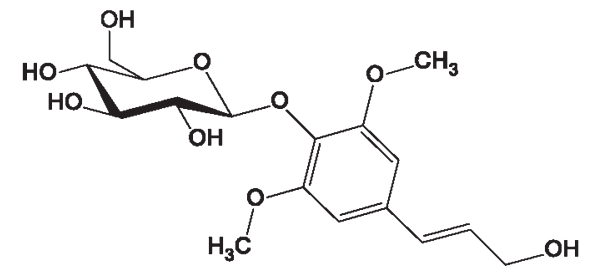

(2)

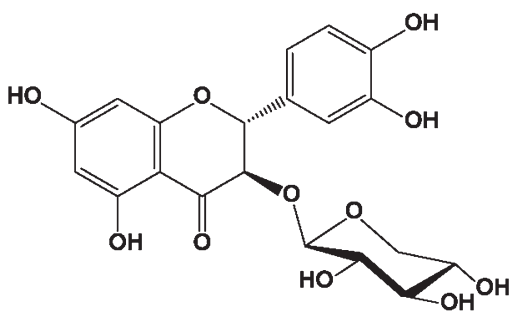

(4)

Figure 8 Chemical structures of determined flavonoid glycosides occurring in beech tissues: (1) Coniferin; (2) Syringin; (3) Taxifolin-3-glucopyranoside; (4) Taxifolin-3-xylopyranoside

Slika 8. Kemijska struktura utvrđenih flavonoida glikozida koji se pojavljuju u tkivima bukve: (1) koniferin; (2) siringin; (3) taksifolin-3-glukopiranozid; (4) taksifolin-3-ksilopiranozid

cis-isoconiferin, $(2 R, 3 R)-(+)$-glucodistylin, $(2 S, 3 S)-(-)-$ glucodistylin and $2 R, 3 R$-taxifolin-3- $D-\beta$-xylopyranosid were identified and completely assigned by $2 \mathrm{D}$ NMR techniques (Dubeler et al., 1997). More isomers of taxifolin-O-hexosides as well as taxifolin-O-pentosides have been qualitatively and quantitatively evaluated in beech bark by means of HPLC-MS/MS analysis (Hofmann et al., 2015). Authors report about the presence of syringin, coniferins, quercetin-O-hexoside, coumaric acid di-O-hexoside, syringic acid-di-O-hexosides, coniferyl alcohol-O-hexoside-O-pentoside in beech bark extracts as well (Hofmann et al., 2015).

Flavonoids can also occur in wood extracts as the aglicon polymers (Fengel and Wegener, 1989). The latter are known as the condensed tannins or proanthocyanidins. It has to be mentioned that the term proanthocyanidins describes bioflavonoids, leucoantocyanidins as well as condensed tannins. The building blocks of most proanthocyanidins are the flavanols catechin and epicate- chin (Dixon et al., 2005), i.e. the characteristic compounds of flavonoid fraction of beech wood extracts. Regarding the inter flavanol linkages as well as the degree of polymerization, the proanthocyanidins are generally divided into A-, B- or C-type proanthocyanidins (Figure 9). Proanthocyanidins were spectrophotometrically evaluated in extracts of intact sapwood as well as in reaction zone of beech by Scalbert et al. (1989) and Baum and Schwarze (2002). This semi-quantitative technique has also been applied for the determination of proanthocyanidins in the stem and knot samples of red hearted beech (Vek et al., 2014). Koch et al. (2003) also reported about the presence of oligomeric flavonoids in acetone-water and methanol-water extracts of beech wood. A relatively large amount of oligomeric polyphenols is characteristic for beech knotwood (Lindberg et al., 2004; Vek et al., 2014). Just recently, Hofmann et al. (2015) have identified and quantified a large number of dimeric and trimeric procyanidins in beech bark by<smiles>Oc1cc(O)c2c(c1)O[C@H](c1ccc(O)c(O)c1)[C@H](O)[C@H]2c1c(O)cc(O)c2c1O[C@H](c1ccc(O)c(O)c1)[C@H](O)C2</smiles>

(1)<smiles>Oc1cc(O)c2c(c1)O[C@]1(c3ccc(O)c(O)c3)Oc3cc(O)c4c(c3[C@@H]1O2)O[C@H](c1ccc(O)c(O)c1)[C@@H](O)C4</smiles>

(2)

Figure 9 Chemical structures of simple dimeric units of type B1 (1) and type A2 (2) proanthocyanidins Slika 9. Kemijska struktura jednostavnih dimernih jedinica tipa B1 (1) i tipa A2 (2) proantocianidina 
<smiles>Cc1c(C)c2c(c(C)c1O)CC[C@@](C)(CCC[C@H](C)CCC[C@H](C)CCCC(C)C)O2</smiles>

(1)

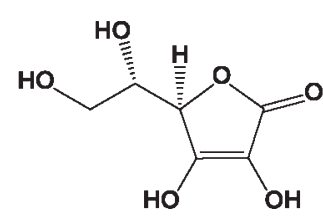

(2)

Figure $10 \alpha$-tocopherol (Vitamin E) (1) and Ascorbic acid (Vitamin C) (2) as identified in the extracts of beech for leaves and wood

Slika 10. (1) $\alpha$-tokoferol (vitamin E) i (2) askorbinska kiselina (vitamin C), kao što je identificirano u ekstraktima bukve, u listovima i u drvu

HPLC-MS/MS. Further on, proanthocyanidins were also identified in the extracts of roots and leaves (Feucht et al., 1994; Beyeler and Heyser, 1997; Feucht et al., 1997). Condensed tannins, present in beech leaves, were investigated by Behrens et al. (2003). The authors demonstrated that proanthocyanidins of beech leaves are built up of procyanidin (catechin and epicatechin) and prodelphinidin units (gallocatechin and epigallocatechin).

Different antioxidants were identified in the beech leaf extracts, i.e. vitamin C (ascorbic acid) and vitamin E ( $\alpha$-tocopherol) (Kunert and Ederer, 1985). Structural formulas for both compounds are presented in Figure 10. It was shown that vitamin E also occurs in the tissues at the bases of living and dead breaches of beech. Furthermore, it can be extracted from these tissues by means of non-polar solvent, i.e. cyclohexane (Vek et al., 2014). Further to the above, vitamin E could be classified as the lipophilic extractive as well.

After all, some of characteristic hydrophilic extractives occurring in tissues of beech trees are biologically active compounds, which make this forest biomass interesting for extraction and further utilization. For instance, antifungal properties against some basidiomycetes were found for catechin and taxifolin by Malterud et al. (1985). Some years later, epicatechin was also reported as the compound with antifungal activity (Ardi et al., 1998; Baum and Schwarze, 2002). In addition to flavonoids, aglycones of cis-coniferin and cis-syringin, i.e. coniferyl alcohol and syringic acid, identified in the methanolic extracts of beech bark were reported as fungicides by Dubeler et al. (1997). Not only pure compounds, but also acetone extract of a beech knot, which was reported to be composed mainly of catechins and flavonoids, showed evident antibacterial properties (Välimaa et al., 2007). Wood and bark extractives of various tree species have attracted much attention due to their possible application in various fields, including nutritional, cosmetic, medical and pharmaceutical industry, as natural biocides, feed additives or in industry of adhesives and leather production etc. Replacement of synthetic, artificial chemicals with more benign natural products, whose recovery has only little or no impact on human health and environment, is one of the important challenges in the field of biorefining forest biomass (Holmbom, 2011).

\section{CONCLUSION}

3. ZAKLJUČAK

It can be summarized that successive extraction using the non-polar and polar solvent, respectively, represents the most frequently used and appropriate way of extraction of different beech material. The extractives can be obtained from grinded samples by using magnetic stirrer, whereas, more aggressive extraction techniques are recommended, e.g. conventional Soxhlet apparatus or various subcritical systems for accelerated extraction (Thurbide and Hughes, 2000; Vek, 2013). From the analytical aspect of view, chromatography in combination with mass spectrometry has been found as the convenient technique for the qualitative and quantitative analysis of extractives. Since stem-wood of beech is generally characterized by the relatively low amounts of extractable compounds, there is a strong need to recognize the appropriate source for extraction. Knots of trees have been presented more times as a very rich source of different polyphenols, perhaps the richest in all of nature as reported by Holmbom (2011) and beech is not an exception (Vek, 2013). Furthermore, a very important step for recovering the target compounds from different parts of a beech tree is the optimization of appropriate and efficient extraction systems (i.e. extraction techniques and solvents) as it was recently demonstrated for beech bark (Hofmann et al. 2015). This short review revealed that the composition of low-molecular fraction of lipophilic and hydrophilic extractives is relatively well investigated, whereas the data on oligomeric fraction of extractable compounds are extremely sparse and require further research efforts.

\section{Acknowledgement - Zahvala}

The authors would like to thank the Slovenian Research Agency (project J-43263-0491-01 and research program P4-0015) for financial support.

\section{REFERENCES}

4. LITERATURA

1. Albert, L.; Hofmann, T.; Nemeth, Z. I.; Retfalvi, T.; Koloszar, J.; Varga, S.; Csepregi, I., 2003: Radial variation of total phenol content in beech (Fagus sylvatica L.) wood with and without red heartwood. Holz RohWerkst., 61 (3): 227-230.

2. Amelio, M.; Rizzo, R.; Varazini, F., 1998: Separation of stigmasta-3,5-diene squalene isomers, and wax esters from olive oils by single high-performance liquid chromatography run. J. Am. Oil Chem. Soc., 75 (4): 527-530 http://dx.doi.org/10.1007/s11746-998-0259-5.

3. Ardi, R.; Kobiler, I.; Jacoby, B.; Keen, N. T.; Prusky, D., 1998: Involvement of epicatechin biosynthesis in the activation of the mechanism of resistance of avocado fruits to Colletotrichum gloeosporioides. Physiol. Mol. Plant 
Pathol., 53 (5-6): 269-285 http://dx.doi.org/10.1006/ pmpp.1998.0181.

4. Bauch, J., 1984: Discoloration in the wood of living and cut trees. IAWA bull., 5 (2): 92-98

http://dx.doi.org/10.1163/22941932-90000869.

5. Baum, S.; Schwarze, F., 2002: Large-leaved lime (Tilia platyphyllos) has a low ability to compartmentalize decay fungi via reaction zone formation. New Phytol., 154 (2): 481-490 http://dx.doi.org/10.1046/j.1469-8137.2002.00390.x.

6. Behrens, A.; Maie, N.; Knicker, H.; Kögel-Knabner, I., 2003: MALDI-TOF mass spectrometry and PSD fragmentation as means for the analysis of condensed tannins in plant leaves and needles. Phytochemistry, 62 (7): $1159-1170$ http://dx.doi.org/10.1016/S0031-9422(02)00660-X.

7. Beyeler, M.; Heyser, W., 1997: The influence of mycorrhizal colonization on growth in the greenhouse and on catechin, epicatechin and procyanidin in roots of Fagus sylvatica L. Mycorrhiza, 7 (4): 171-177 http://dx.doi.org/10.1007/s005720050178.

8. Bodirlau, R.; Teaca, C. A.; Spiridon, I., 2008: Chemical Modification of Beech Wood: Effect on Thermal Stability. BioResources, 3 (3): 789-800.

9. Bosshard, H. H., 1974: Holzkunde. Band 2. Zur Bilogie, Physic und Chemie des Holzes., Basel, Stuttgart, Birkhäuser Verlag.

10. Brighente, I. M. C.; Dias, M.; Verdi, L. G.; Pizzolatti, M. G., 2007: Antioxidant activity and total phenolic content of some brazilian species. Pharmaceutical Biology, 45 (2): $156-161$

http://dx.doi.org/10.1080/13880200601113131.

11. Brignolas, F.; Lacroix, B.; Lieutier, F.; Sauvard, D.; Drouet, A.; Claudot, A. C.; Yart, A.; Berryman, A. A.; Christiansen, E., 1995: Induced Responses in Phenolic Metabolism in 2 Norway Spruce Clones after Wounding and Inoculations with Ophiostoma-Polonicum, a Bark Beetle-Associated Fungus. Plant Physiol., 109 (3): 821827.

12. Challinor, J. M., 1996: Characterisation of wood extractives by pyrolysis-gas chromatography/mass spectrometry of quaternary ammonium hydroxide extracts. Journal of Analytical and Applied Pyrolysis, 37 (1): 1-13 http://dx.doi.org/10.1016/0165-2370(96)00937-0.

13. Dietrichs, H. H., 1964a: Chemisch-physilogische untersuchungen über die splint-kern-umwandlung der rotbuche (Fagus sylvatica L.) - Ein Beitrag zur Frage der Holzverkernung. Mitteilungen der BFH 58.

14. Dietrichs, H. H., 1964b: Das verhalten von kohlenhydraten bei der holzverkernung. Holzforschung, 18: 14$24 \mathrm{http}: / /$ dx.doi.org/10.1515/hfsg.1964.18.1-2.14.

15. Dixon, R. A.; Xie, D. Y.; Sharma, S. B., 2005: Proanthocyanidins - a final frontier in flavonoid research? New Phytologist, 165 (1): 9-28 http://dx.doi.org/10.1111/j.1469-8137.2004.01217.x.

16. Dubeler, A.; Voltmer, G.; Gora, V.; Lunderstadt, J.; Zeeck, A., 1997: Phenols from Fagus sylvatica and their role in defence against Cryptococcus fagisuga. Phytochemistry, 45 (1): 51-57 http://dx.doi.org/10.1016/ S0031-9422(96)00771-6.

17. Fengel, D.; Wegener, G., 1989: Wood: chemistry, ultrastructure, reactions. Berlin - New York, Walter de Gruyter.

18. Feucht, W.; Treutter, D.; Christ, E., 1994: Accumulation of flavanols in yellowing beech leaves from forest decline sites. Tree Physiol., 14: 403-412 http://dx.doi.org/10.1093/treephys/14.4.403.
19. Feucht, W.; Treutter, D.; Christ, E., 1997: Role of flavanols in yellowing beech trees of the Black Forest. Tree Physiol., 17: 335-340 http://dx.doi.org/10.1093/treephys/17.5.335.

20. Gallina Toschi, T.; Bendini, A.; Lercker, G., 1996: Evaluation of 3,5-stigmastadiene content of edible oils: Comparison between the traditional capillary gas chromatographic method and the on-line high performance liquid chromatography-capillary gas chromatographic analysis. Chromatographia, 43 (3-4): 195-199 http://dx.doi.org/10.1007/BF02292950.

21. Hillis, W. E., 1987: Heartwood and tree exudates. Berlin - New York, Springer-Verlag http://dx.doi.org/10.1007/978-3-642-72534-0.

22. Hofmann, T.; Albert, L.; Retfalvi, T., 2004: Quantitative TLC analysis of (+)-catechin and (-)-epicatechin from Fagus sylvatica L. with and without red heartwood. J. Planar Chromatogr., 17: 350-354 http://dx.doi.org/10.1556/JPC.17.2004.5.5.

23. Hofmann, T.; Albert, L.; Retfalvi, T.; Visi-Rajczi, E.; Brolly, G., 2008: TLC analysis of the in-vitro reaction of beech (Fagus sylvatica L.) wood enzyme extract with catechins. Journal of Planar Chromatography, 21 (2): 83$88 \mathrm{http} / / / \mathrm{dx}$. doi.org/10.1556/JPC.21.2008.2.2.

24. Hofmann, T.; Nebehaj, E.; Albert, L., 2015: The highperformance liquid chromatography/multistage electrospray mass spectrometric investigation and extraction optimization of beech (Fagus sylvatica L.) bark polyphenols. Journal of Chromatography A, 1393: 96-105 http://dx.doi.org/10.1016/j.chroma.2015.03.030.

25. Holmbom, B., 1999: Extractives. In: Sjöström E., Alén R. (eds): Analytical methods in wood chemistry, pulping and papermaking. Berlin, Springer-Verlang, pp. 316 http://dx.doi.org/10.1007/978-3-662-03898-7_5.

26. Holmbom, B., 2011: Extraction and utilisation of nonstructural wood and bark components. In: Alén R. (ed): Biorefining of forest resources. Helsinki, Paper Engineers' Association/Paperi ja Puu Oy, pp. 178-224.

27. Irmouli, M.; Haluk, J. P.; Kamdem, D. P.; Charrier, B., 2002: Chemical characterization of beech condensate. J. Wood Chem. Technol., 22 (2-3): 127-136 http://dx.doi.org/10.1081/WCT-120013357.

28. Jansson, M. B.; Nilvebrant, N. V., 2009: Wood extractives. In: Ek M., Gellerstedt G., Henriksson G. (eds): Wood Chemistry and Wood Biotechnology (Pulp and Paper Chemistry and Technology). vol Volume I, Berlin, De Gruyter, pp. 147-171 http://dx.doi.org/ 10.1515/9783110213409.147.

29. Kai, Y., 1991: Chemistry of Extractives. In: Hon D. N. S., Shiraishi N. (eds): Wood and Cellulosic Chemistry. New York, Marcel Dekker, Inc., pp. 215-255.

30. Koch, G., 2002: Rotkernige Buche - Holz mit Characte. Holzabsatzfonds - Absatzförderungsfond der deutschen Forst- und Holzwirtschaft: 8.

31. Koch, G.; Puls, J.; Bauch, J., 2003: Topochemical characterisation of phenolic extractives in discoloured beechwood (Fagus sylvatica L.). Holzforschung, 57 (4): 339345 http://dx.doi.org/10.1515/HF.2003.051.

32. Košikova, B.; Slavikova, E.; Kacik, F., 2008: Biodegradability of extractives in sound and biologically decayed beech by various yeast species. Wood Res., 53 (3): 9-16.

33. Kubel, H.; Weissmann, G., 1988: Investigations on the cancerogenicity of wood dust-the extractives of beech and spruce. Holz Roh- Werkst., 46 (6): 215-220 http://dx.doi.org/10.1007/BF02608116.

34. Kunert, K. J.; Ederer, M., 1985: Leaf aging and lipidperoxidation - the role of the antioxidants vitamin-C and vitamin-E. Physiol. Plant., 65 (1): 85-88 http://dx.doi.org/10.1111/j.1399-3054.1985.tb02364.x 
35. Lekounougou, S.; Mounguengui, S.; Dumarçay, S.; Rose, C.; Courty, P. E.; Garbaye, J.; Gérardin, P.; Jacquot, J. P.; Gelhaye, E., 2008: Initial stages of Fagus sylvatica wood colonization by the white-rot basidiomycete Trametes versicolor: Enzymatic characterization. International Biodeterioration \& Biodegradation, 61 (4): 287-293 http://dx.doi.org/10.1016/j.ibiod.2007.06.013.

36. Lindberg, L. E.; Willför, S. M.; Holmbom, B. R., 2004: Antibacterial effects of knotwood extractives on paper mill bacteria. Journal of Industrial Microbiology and Biotechnology, 31 (3): 137-147 http://dx.doi.org/10.1007/s10295-004-0132-y

37. Mali, B.; Torelli, N.; Piškur, M.; Levanič, T.; Kraigher, H., 2009: Rdeče srce kot dejavnik kakovosti bukovine na treh rastiščih v Sloveniji (Red heart as an essential factor of Beech wood quality at three different sites in Slovenia). In: Humar M., Kraigher H. (eds): Trajnostna raba lesa $\mathrm{v}$ kontekstu sonaravnega gospodarjenja $\mathrm{z}$ gozdovi (Studia forestalia Slovenica). Ljubljana, Gozdarski inštitut Slovenije, Silva Slovenica, pp. 79-88.

38. Malterud, K. E.; Bremnes, T. E.; Faegri, A.; Moe, T.; Dugstad, E. K. S.; Anthonsen, T.; Henriksen, L. M., 1985: Flavonoids from the Wood of Salix caprea as Inhibitors of Wood-Destroying Fungi. J. Nat. Prod., 48 (4): 559-563 http://dx.doi.org/10.1021/np50040a007.

39. Mammela, P., 2001: Phenolics in selected European hardwood species by liquid chromatography-electrospray ionisation mass spectrometry. Analyst, 126 (9): 1535-1538 http://dx.doi.org/10.1039/b104584a.

40. Masson, G.; Baumes, R.; Puech, J. L.; Razungles, A., 1997: Demonstration of the presence of carotenoids in wood: Quantitative study of cooperage oak. J. Agric. Food Chem., 45 (5): 1649-1652 http://dx.doi.org/10.1021/jf960668q.

41. Mounguengui, S.; Dumarcay, S.; Gerardin, P., 2007: Investigation on catechin as a beech wood decay biomarker. International Biodeterioration \& Biodegradation, 60 (4): $238-244$ http://dx.doi.org/10.1016/j.ibiod.2007.03.007.

42. Naczk, M.; Shahidi, F., 2004: Extraction and analysis of phenolics in food. Journal of Chromatography A, 1054 (1-2): 95-111 http://dx.doi.org/10.1016/j.chroma.2004.08.059.

43. Naczk, M.; Shahidi, F., 2007: Phenolics in cereals, fruits and vegetables: Occurrence, extraction and analysis. J. Pharm. Biomed. Anal., 43 (2): 798-798 http://dx.doi. org/10.1016/j.jpba.2006.09.034.

44. Oven, P.; Merela, M.; Mikac, U. A.; Sersa, I., 2008: 3D magnetic resonance microscopy of a wounded beech branch. Holzforschung, 62 (3): 322-328.

45. Oven, P.; Torelli, N.; Shortle, W. C.; Zupancic, M., 1999: The formation of a ligno-suberised layer and necrophylactic periderm in beech bark (Fagus sylvatica L.). Flora, 194 (2): 137-144.

46. Pearce, R. B., 1996: Antimicrobial defences in the wood of living trees. New Phytol., 132 (2): 203-233 http:// dx.doi.org/10.1111/j.1469-8137.1996.tb01842.x.

47. Pearce, R. B., 2000: Decay development and its restriction in trees. Forestry Abstracts 1976037 06141, 26 (1): $1-11$.

48. Perra, B.; Haluk, J. P.; Metche, M., 1993: Extraction of suberin and lignin from beech barks (Fagus sylvatica L.). Holzforschung, 47 (6): 486-490 http://dx.doi.org/ 10.1515/hfsg.1993.47.6.486.

49. Pietarinen, S.; Willför, S.; Ahotupa, M.; Hemming, J.; Holmbom, B., 2006: Knotwood and bark extracts: strong antioxidants from waste materials. J. Wood Sci., 52 (5): 436-444 http://dx.doi.org/10.1007/s10086-005-0780-1.
50. Pirvu, L.; Armatu, A.; Bubueanu, C.; Pintilie, G.; Nita, S., 2010: Obtaining and chemical characterization of some vegetal extracts with corrosion-scaling inhibition properties. Part I. Fagus sylvatica and Alii cepae bulbus extracts. Rom. Biotech. Lett., 15 (6): 5683-5689.

51. Pišova, M.; Souček, M., 1973: Triterpenes and steroids from Fagus sylvatica. Phytochemistry, 12 (8): 2068$2068 \mathrm{http} / / / \mathrm{dx}$. doi.org/10.1016/S0031-9422(00)91547-4.

52. Rowe, J. W.; Conner, A. H., 1979: Extractives in eastern hardwoods - a review. Madison, Wisconsin, U.S. Department of Agriculture, Forest Service, Forest Products Laboratory.

53. Sachsse, H., 1991: Kerntypen der Rotbuche. Forstarchiv, 62: $238-242$.

54. Scalbert, A.; Monties, B.; Janin, G., 1989: Tannins in wood: Comparison of different estimation methods. J. Agric. Food Chem., 37 (5): 1324-1329 http://dx.doi.org/10.1021/jf00089a026.

55. Schwarze, F. W. M. R.; Baum, S., 2000: Mechanisms of reaction zone penetration by decay fungi in wood of beech (Fagus sylvatica). New Phytol., 146 (1): 129-140 http://dx.doi.org/10.1046/j.1469-8137.2000.00624.x.

56. Sherwood, P.; Bonello, P., 2013: Austrian pine phenolics are likely contributors to systemic induced resistance against Diplodia pinea. Tree Physiol., 33 (8): 845-854 http://dx.doi.org/10.1093/treephys/tpt063.

57. Sixta, H.; Promberger, A.; Koch, G.; Gradinger, C.; Messner, K., 2004: Influence of beech wood quality on bisulfite dissolving pulp manufacture. Part 1: Influence of log storage on pulping and bleaching. Holzforschung, 58 (1): 14-21 http://dx.doi.org/10.1515/HF.2004.003.

58. Slanina, J.; Glatz, Z., 2004: Separation procedures applicable to lignan analysis. Journal of Chromatography B, 812 (1-2): 215-229 http://dx.doi.org/10.1016/j.jchromb.2004.06.047.

59. Taiz, L.; Zeiger, E., 2002: Plant Physiology. 3rd ed., Sunderland, Sinauer Associates.

60. Thurbide, K. B.; Hughes, D. M., 2000: A rapid method for determining the extractives content of wood pulp. Ind. Eng. Chem. Res., 39 (8): 3112-3115 http://dx.doi.org/10.1021/ie0003178.

61. Torelli, N., 1984: The ecology of discolored wood as i1lustrated by beech (Fagus sylvatica L.). IAWA Bull., 5 (2): 121-127 http://dx.doi.org/10.1163/22941932-90000875.

62. Torelli, N., 2003: Ojedritev-vloga in proces (Heartwood formation-function and process). Les wood, 55: 368-379.

63. Torelli, N.; Križaj, B.; Oven, P., 1994: Barrier zone (CODIT) and wound-associated wood in beech (Fagus sylvatica L.). Holzforsch. Holzverwert., 46 (3): 49-51.

64. Torelli, N.; Oven, P., 1996: Occurrence of suberin in the discoloured wood ("red heart") in beech (Fagus sylvatica L.). Iawa J., 17 (3): 265.

65. Umezawa, T., 2000: Chemistry of extractives. In: Hon D. N. S., Shiraishi N. (eds): Wood and Cellulosic Chemistry. New York, Marcel Dekker, Inc., pp. 213-241.

66. Välimaa, A.-L.; Honkalampi-Hämäläinen, U.; Pietarinen, S.; Willför, S.; Holmbom, B.; von Wright, A., 2007: Antimicrobial and cytotoxic knotwood extracts and related pure compounds and their effects on food-associated microorganisms. International Journal of Food Microbiology, 115 (2): 235-243 http://dx.doi.org/ 10.1016/j.ijfoodmicro.2006.10.031.

67. Vek, V., 2013: Extractives in wounded wood and knots of common beech (Fagus sylvatica L.). PhD Thesis. Ljubljana, University of Ljubljana, Biotechnical faculty.

68. Vek, V.; Oven, P.; Humar, M., 2013a: Phenolic extractives of wound-associated wood of beech and their fungicidal effect. Int. Biodeterior. Biodegrad., 77: 91-97 http://dx.doi.org/ 10.1016/j.ibiod.2012.10.013. 
69. Vek, V.; Oven, P.; Poljanšek, I., 2013b: Content of total phenols in the red heart and wound-associated wood in beech (Fagus sylvatica L.). Drvna industrija, 64 (1): 25$32 \mathrm{http}: / / \mathrm{dx}$. doi.org/10.5552/drind.2013.1224.

70. Vek, V.; Oven, P.; Poljanšek, I.; Ters, T., 2015: Contribution to Understanding the Occurrence of Extractives in Red Heart of Beech. BioResources, 10 (1): 970-985.

71. Vek, V.; Oven, P.; Ters, T.; Poljansek, I.; Hinterstoisser, B., 2014: Extractives of mechanically wounded wood and knots in beech. Holzforschung, 68 (5): 529-539 http://dx.doi.org/10.1515/hf-2013-0003.

72. Wagenführ, R., 1996: Holzatlas. 4. edn, Leipzig, Fachbuchverlag Leipzig http://dx.doi.org/ 10.1163/22941932-90001585.

73. Wernsdörfer, H.; Constant, T.; Mothe, F.; Badia, M. A.; Nepveu, G.; Seeling, U., 2005: Detailed analysis of the geometric relationship between external traits and the shape of red heartwood in beech trees (Fagus sylvatica L.). Trees, 19 (4): 482-491 http://dx.doi.org/10.1007/s00468-005-0410-y.

74. Willför, S. M.; Smeds, A. I.; Holmbom, B. R., 2006: Chromatographic analysis of lignans. Journal of Chromatography A, 1112 (1-2): 64-77

http://dx.doi.org/10.1016/j.chroma.2005.11.054.
75. Zell, J.; Hanewinkel, M.; Seeling, U., 2004: Financial optimisation of target diameter harvest of European beech (Fagus sylvatica) considering the risk of decrease of timber quality due to red heartwood. Forest Policy and Economics, 6 (6): 579-593 http://dx.doi.org/ 10.1016/S1389-9341(03)00007-8.

76. Zule, J.; Može, A., 2003: GC analysis of extractive compounds in beech wood. J. Sep. Sci., 26 (14): 1292-1294 http://dx.doi.org/10.1002/jssc.200301416.

\section{Corresponding address:}

Prof. PRIMOŽ OVEN, Ph.D.

Biotechnical Faculty

Department of Wood Science and Technology

Rožna dolina, Cesta VIII/34

1000 Ljubljana, SLOVENIA

e-mail: primoz.oven@bf.uni-lj.si 